\title{
Melanoma-Associated Antigen C2
}

National Cancer Institute

\section{Source}

National Cancer Institute. Melanoma-Associated Antigen C2. NCI Thesaurus. Code C104529.

Melanoma-associated antigen C2 (373 aa, $41 \mathrm{kDa}$ ) is encoded by the human MAGEC2 gene. This protein may enhance ubiquitin ligase activity. 